\title{
A Review on Vegetative Propagation of Aonla
}

\author{
Kanika and Deepika Saxena* \\ Department of Horticulture, School of Agriculture, Lovely Professional University, \\ Phagwara, Punjab, India \\ *Corresponding author
}

\section{A B S T R A C T}

\begin{tabular}{|l|}
\hline Ke y w o r d s \\
$\begin{array}{l}\text { Vegetative } \\
\text { Propagation, Aonla }\end{array}$ \\
\hline Article Info \\
\hline $\begin{array}{l}\text { Accepted: } \\
\text { 07 November } 2020 \\
\text { Available Online: } \\
\text { 10 December } 2020\end{array}$ \\
\hline
\end{tabular}

Aonla being a vegetatively propagated crop comes to commercial orchard establishment since seedlings can only be used as good rootstocks as there are high chances of variability in the tree grown from seeds. It can be propagated by grafting, budding, etc. out of which soft wood grafting is experienced to be most successful but veneer and cleft grafting is also attempted successfully. Hence in this paper the work of several scientists have been reviewed for different vegetative methods being studied in the aonla propagation.

\section{Introduction}

The aonla (Emblica officinalis syn Phyllanthus emblica), a very primordial minor fruit crop, quite known for its invigorating properties, it is also known for being lush bearing crop. It belongs to the family Euphorbiaceae and is known as amla, amli and nelliand much more in different parts of India, Nepal and other countries. This fruit is a very important crop as it has a large aryuvedic and homeopathic medicine. It is a wholesome fruit with highest vitamin C among fruits after Barbados cherry (Asenjo 1953). Most suitable for areas like Rajasthan where low precipitation is available. Production belt of India for Aonla varies from Haryana- Bewal, Gurugram, Himachal
Pradesh - Palampur, Bilaspur, Hamirpur, Karnataka- Mysore, Madhya Pradesh, Tamil Nadu, Uttar Pradesh. A lot of indigenous and ayurvedic medicines are usually made by taking Aonla as the main constituent. The nutritive value of this fruit is really high, with a high percentage of Vitamin $\mathrm{C}$ content. It is a deciduous tree with deep rooted and sparse foliage. It is an ideal plant amicable for 2-3 tier cropping system. Type of propagation used in aonla is usually vegetative when comes to commercial orchard establishment since seedlings can only be used as a good rootstocks as there are high chances of variability in the tree grown from seeds. It can be propagated by grafting, budding, etc. out of which soft wood grafting is experienced to be most successful but veneer and cleft 
grafting is also attempted successfully. Area and Production Data According to National
Horticulture Board 2016-2017, 2017-2018 Area in '000 Ha Production in '000 MT

\begin{tabular}{|c|c|c|c|c|}
\hline Crop & \multicolumn{2}{|c|}{ 2016-2017 } & \multicolumn{2}{c|}{ 2016-2017 } \\
\hline Fruit & AREA & PRODUCTION & AREA & PRODUCTION \\
\hline Aonla & 93 & 1075 & 93 & 1075 \\
\hline
\end{tabular}

State wise Area, Production and Productivity of Aonla during 1999-2000

\begin{tabular}{|c|c|c|c|}
\hline State & $\begin{array}{c}\text { Area } \\
(\mathbf{0 0 0} \text { Ha.) }\end{array}$ & $\begin{array}{c}\text { Production } \\
\text { ('000 MT) }\end{array}$ & $\begin{array}{c}\text { Productivity } \\
\text { (MT/Ha.) }\end{array}$ \\
\hline Uttar Pradesh & 15.75 & 63.00 & 4.0 \\
\hline Gujarat & 10.05 & 12.00 & 1.5 \\
\hline Rajasthan & 5.00 & 6.00 & 1.2 \\
\hline Maharashtra & 4.00 & 5.60 & 1.4 \\
\hline Haryana & 0.60 & 3.10 & 5.2 \\
\hline Mizoram & 0.07 & 0.20 & 2.9 \\
\hline Tamil Nadu & 5.50 & 8.25 & 1.5 \\
\hline Andhra Pradesh & 3.00 & 4.50 & 1.5 \\
\hline Karnataka & 1.80 & 2.70 & 1.5 \\
\hline Bihar & 1.35 & 2.00 & 1.5 \\
\hline Others & 2.50 & 3.75 & 1.5 \\
\hline TOTAL & $\mathbf{4 9 . 6 2}$ & $\mathbf{1 1 1 . 1 0}$ & - \\
\hline
\end{tabular}

This is a fruit of sub - tropical region but its cultivation in tropical climate is also successful. The tree can tolerate winds and frost. Mature trees of aonla can also tolerate freezing temperature and hot temperatures till 46 degrees. The fruit remains dormant during summer. So, it is best suited crop for arid region. Aonla is indigenous to South-East Asia, it is said to be native to India, Ceylon, Jalaysia and China. This crop is variedly found in different states throughout tropical India, even upto elevation $1500 \mathrm{~m}$ in South India. In Uttar Pradesh and Gujrat main orchards of Aonla can be seen very prominantly. The eastern districts of UP like Faizabad, Pratagarh, Allahabad and Yaranasi are the main aonla growing areas of India.

Emblica officinalis is commonly known as "Indian Gooseberry", belongs to family Euphorbiaceae, it is a small medium sized tree with a crooked trunk and spreading branches, grayish-green bark that peels off like flakey skin. It is usually a deciduous tree with the leaves simple, sub sessile and closely set along branch lets. The leaves are light greenish in color and called as pinnate leaves. The flowers are borne in axillary fascicles and are greenish-yellow in color. The fruit is globosely and almost $1.5-2.5 \mathrm{~cm}$ in diameter. They are fleshy, six lobed and have six trig nous seed. They are light green in color when not completely ripen and slowly turns lightyellow to brick red when matures. The seeds are acrid and sweet and are useful in treating many diseases and also helps in recovering from vomiting, luekorrehoea etc. (Wali et al., 2015).

The fruit of aonla is highly nutritive and after Barbados cherry it is said to have highest Vitamin C content (Asenjo, 1953). Different forms of ascorbic acid content have been seen found in aonla by different researchers. 
(Sastry et al., 1956) noted the stability of ascorbic acid and presence of astringency in aonla fruit is ay be because $f$ presence of polyphenols or lcucoanthocyanins. Even in dried form the aonla fruit still retains the content ascorbic acid and other constituents. And evaluation done for different products revealed that dried aonla had maximum nutritive value followed by chavyvanprash, aonla preserve, pickle, brined aonla fruits (Naik and Chundawat, 1993). It is also a high source of pectin which is useful for making jam and jellies. It acts as laxative, diuretic and refrigerant also.

Freshly harvested seeds of aonla do not germinate even if exposed to favourable conditions of germination owing to seed dormancy (Srimathi et al., 2000). Aonla if produced by seeds may produce small-sized fruit, inferior in quality and they do not come true-to-type (Bharathkumar, 2019). Some factors like internal physiological or morphological i.e. hard, thick testa, erroneous storage or handling may cause dormancy (primary and secondary). Such seeds may require special treatments like stratification, scarification, soaking in water, growth regulators etc. for overcoming dormancy.

So vegetative propagation is the only method that can be used in crops like aonla as vegetative propagated crops do not undergo any mutations or show any changes that differ them from their parents plant, although shield/patch budding has been successfully tried in aonla but it requires high knowledgeable labour for its performance and high success is required, it is also time consuming process and skilled labour is required, whereas softwood grafting is also being performed and said to be simple and less skill are required for it and also consumes less time as compared to the other. The season and rootstock whereas play an important role in success graft reunion of aonla. A fair high temperature along with rainy season and high humidity with a combination of well matured rootstock is hospitable for quick callus production which will in return ensure the formation of strong fusion of stock and scion.

A very few reports have been reported on micropropagation of aonla. Verma and Kant induced shoot prolification from nodal stem explants after 4 weeks of culture on modified MS medium supplemented with BA (3.0$5.0 \mathrm{mg} / \mathrm{l})$ and NAA $(0.5 \mathrm{mg} / \mathrm{l})$. However, bud break was observed in only $8-10 \%$ f explants, and a maximum 3-4 shoots per explants were produced. Leaching of phenolics resulted in the loss $\mathrm{f}$ almost $90 \%$ of the cultures. Shoot prolification was only observed on explants collected and inoculated in February-April or August-October.

Drawbacks of not growing aonla with seeds may also be visible as when we propagate vegetatively there is high chance of lackness of genetice variability which will never produce a new outcome or there will be no betterments carried on further in the crop particularly. With the time passage there may be chances that we face degeneration of the plant due to lack of sexual stimulus. There are chances of high competition between members of same species and this can be caused due to overcrowding of large number of plants near parent plant. When we sow the seeds for the purpose of propagation there are high chances of late fruiting or even no fruits are possible in this situation and it starts $t$ bear fruits much later than that of vegetatively propagated fruit trees.

Grafting is an ancient method used to propagate the plants by joining them all together or combining their stems of one plant with the bark or other plant. The top portion of the graft is known as 'scion' and the part connected to root base is called rootstock Wang Y Q, (2011). It is an advanced 
technique that is been used by orchardists used to add one tissue from one plant to the other. Plant tissues have an ability to grow new vascular tissue and the process of grafting is used by taking the advantage of this ability (Hennig and Köhler, 2010). The vascular tissue of the main plant joins with the vascular tissue of the other added plant, keeping the new tissue alive and growing. The process of joining these vascular tissues together is also known as inosculation.

Major types of grafting are consolidated so as to give a proper view on them and how they are used:

Cleft grafting: It is a very old method of vegetative propagation, it is very simple and very frequently used method, for this the rootstock must be split or made a cleft right from the centre of the stock a smooth perpendicular cut to the main axis, then from the base of the scion make a tapered cut, make sure there is a bud near the basal end of the scion. Then make a smooth fit of both stock and the scion and joined together.

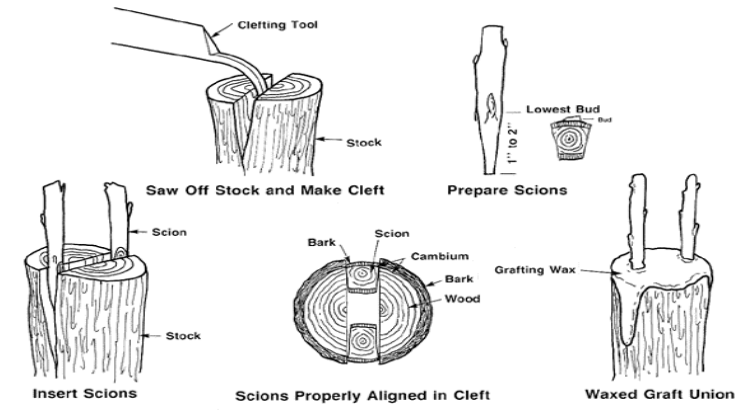

Source: https://content.ces.ncsu.edu/grafting-andbudding-nursery-crop-plants

Bark grafting: For bark graft the rootstock needs to be made a vertical slit and scion needs a tapered wedge and then scion to be inserted into the cut surface of the stock. Then join them together making sure of their all tissues being held together and then tightly tied together so that their tissues stay intact and doesn't get loosen up.

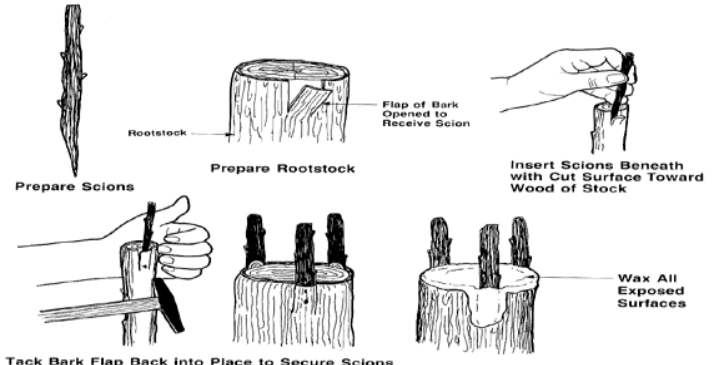

Source: https://content.ces.ncsu.edu/grafting-andbudding-nursery-crop-plants

Side-veneer grafting: Inserted downward cut with a flap kept open and some wood still connected of the potted stock. Making a sloping cut for scion at the base and joining them with polyethene or grafting tape.

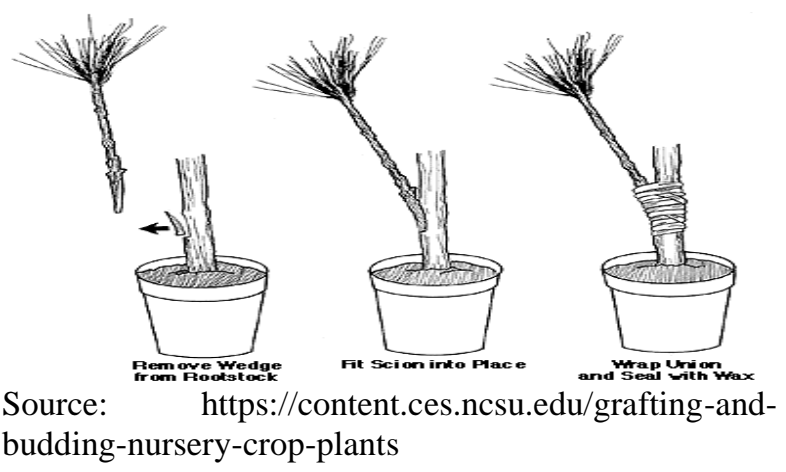

Splice grafting: Diagonal cut on both the stock and the scion. Fitting them similarly and connected.

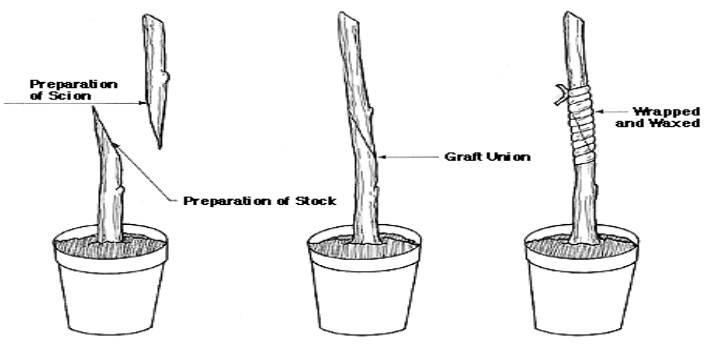

Source: https://content.ces.ncsu.edu/grafting-andbudding-nursery-crop-plants

Whip or tongue grafting: With the grafting knife a slit made right in the middle of flat surfaced rootstock and scion made sharp with diagonal slits at both the basal edges so that it fits the slit of stock. 


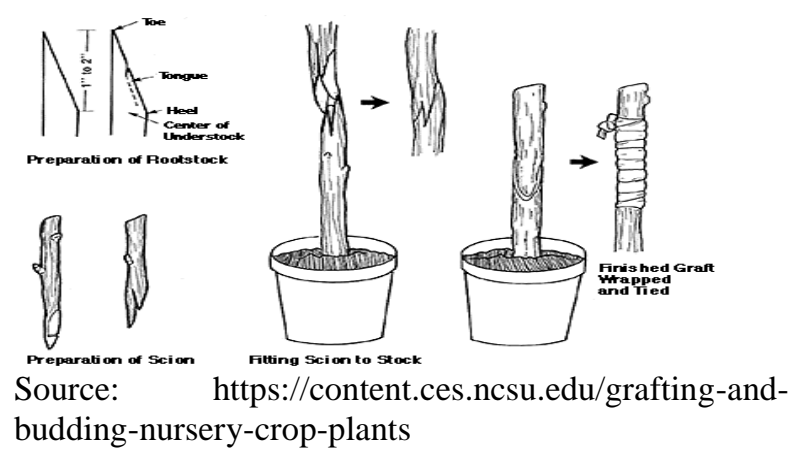

Saddle grafting: It is somehow an opposite form of Whip grafting or Tongue Grafting, in this one the stock is made like a sharp edgy from both sides and a slit made in the middle of scion and made it fit well with the stock.

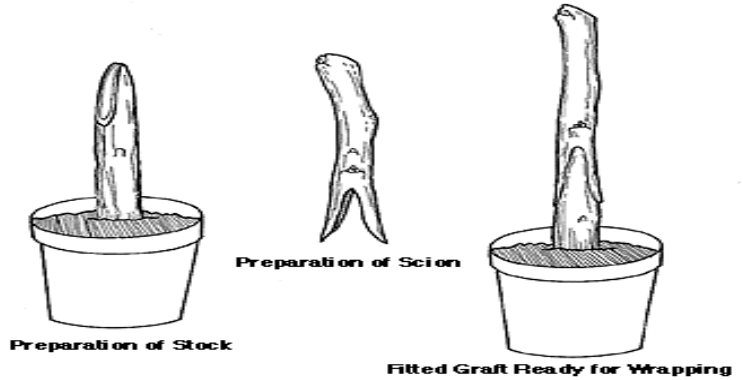

Source: https://content.ces.ncsu.edu/grafting-andbudding-nursery-crop-plants

Bridge grafting: In this grafting a bridge is formed so as to overcome the damaged area, so the size of scion first chosen must be twice longer than the damaged portion. The tapered cut made at both the ends of the scion. Scrap off the damaged part of the tissue so that graft is made on healthy tissue then cut a flap on the bark same the size of the scions, gently fit them together and tie them.

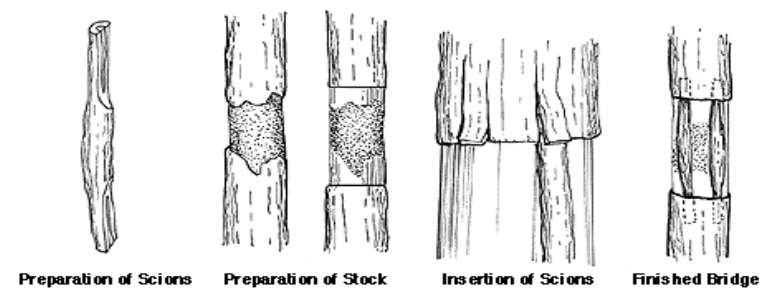

Source: https://content.ces.ncsu.edu/grafting-andbudding-nursery-crop-plants

To have a clear view of present review on "Aonla propagation by grafting" has been proposed with following objectives:

To find out the appropriate time for wedge grafting of aonla.

To find out the effect of environmental condition on the success, survivability and growth of To grafted plants of aonla.

To study the effect of wedge grafting on aonla.

\section{Review of literature}

The literature for current investigation with title "Studies on impact of grafting time and environment on multiplication of aonla by wedge grafting" has been reviewed as below:

Panchbhai et al., (2006) researched that Aonla being sub-tropical fruit can be propagated by seeds as we seen in usual but that results in high variability. In his research he investigated that soft wood grafting and patch budding being performed on 5-12 month old local seedlings which had the girth of 2.0-2.5 $\mathrm{cm}$ at its collar region and scion of $8-10 \mathrm{~cm}$ length. The highest success rate was observed in soft-wood grafting in the month of January (86\%) whereas in patch budding it has highest in August (40\%).

Jadia et al., (2014-2015) found out that in Guava crop proper care during the growth and care of guava was not taken care and new method of selection during scion should be done, these are some reasons due to which the product was not that abundant in the past times. During this research for the whole year they noticed that wedge grafting effects in rapid multiplication of the crops throughout the whole year, whether it be in green house conditions or in open fields. In this paper they have seen the success rate of wedge grafting in the regions of Chitrakoot and the most suitable time was $20^{\text {th }}$ November to $5^{\text {th }}$ 
January while kept in poly house and $5^{\text {th }}$ January to $5^{\text {th }}$ February in open field conditions of Chitrakoot region of India.

Chouksey et al., (2016) performed an experiment on finding the effect of grafting date and preconditioning on graft success of guava (Psidium guajava L.) by performing wedge grafting during the month of October 2014- June 2015. The observation showed that deblading when done 8 days before grafting showed much better results as to be counted in all other attributes. There were many results that were taken as main attributes of this research work; shoot length, days taken to graft sprouting, percent graft success, percent graft sprouting and number of leaves per graft 90 days after grafting. Later on the result showed that minimum days (7.25 days) taken to graft sprouting and maximum bud sprouting percent $(44.76 \%)$ was recorded in $5^{\text {th }}$ march grafting and graft success percent $(68.08 \%)$, shoot length (14.00 $\mathrm{cm})$ and number (18.40) observed maximum in plants grafted on $20^{\text {th }}$ February recorded after 90 days of grafting.

Patel et al., (2015) recorded in his work that when they tried tongue grafting on $15^{\text {th }}$ October got a record of least days of sprouting (15.00 days), highest success rate of graft $(98 \%)$, with survival rate $(85.78 \%)$. Wedge grafting on the same date also performed very well with a successful graft $(96 \%)$ and plant survival $(82.47 \%)$. The parameters of vegetative growth of the grafts after 3 months showed highest plant height $(65.38 \mathrm{~cm})$, number of leaves $(70.87)$ per plant, scion $(8.48 \mathrm{~mm})$ and rootstock $(8.77 \mathrm{~mm})$ nytongie grafting. Total highest carbohydrate content $(18.48 \%)$ where C:N ratio (6.44), phenol content $(3.14 \%)$ in leaves when wedge graft was done on $30^{\text {th }}$ September while minimum total carbohydrate content (13.86\%), C:N ratio (4.18) and phenol content all were recorded during tongue graft on $30^{\text {th }}$ October. After this, there is a possibility that Sohiong may be grafted by both the methods in the $2^{\text {nd }}$ week of October under the conditions of Meghalaya (mid hills) for getting better results.

Kumari et al., (2015) in their study they performed different gene expressions between organs of scion and rootstock of homegraft (Arbidopsis thaliana). With the help of MapMan and Gene Ontology enrichment analysis it $\mathrm{s}$ exposed differentially expressed genes from numerous functional categories related to stress responses in the emerging flower buds and leaves of scion and rootstock. Meta analysis suggested induction of draughttype responses in flower buds and leaves of the scion. In this experiment, the flower bud of scion showed over-representation of transcription factor genes, for example, Homeobox, NAC, MYB, bHLH, B3, C3HC4, PLATZ etc. the scion leaves showed higher accumulation of the regulatory genes for flower development such as SEPALLATA 14, Jumonji $\mathrm{C}$ and AHL16. Differential transcription of genes related to ethylene, gibberellic acid and other stimuli was observed between scion and rootstock. This research will help to better understand the molecular basis of grafting and acclimation of scion on rootstock.

Kaushal et al., (2017) in their study planned to standardize the required time of wedge grafting and found out the effect of polycap in guava cv. HisarSafeda. They grafted the rootstocks of guava in a different time interval ie. Second fortnight of January, first and second fortnight of February and first fortnight of March with and without polycap. Where the grafting done with polycap in second fortnight of February under open field conditions gave highest rate of success (83.33\%), whereas minimum graft $(10.00 \%)$ was observed when graft was done in second fortnight of January. 
Beshir et al., (2019) found out in their study that was conducted in Harbu fruit nursery site of Amhara region in the period of June 2015 to December 2016 so that they can get maximum graft success of grafted mango by using appropriate grafting time and technique with the use of apple variety as a scion. The study showed the main and interaction effects of grafting time with technique gave a good results with respect to various factors ie., bud break, scion diameters, rootstock diameter, rootstock length, number of leaves per graft and graft success in mango.

Gurjar et al., (2012) while performing their research found that the results of their work taken for first sprouting, bud bursting percentage and graft survival percentage represented that the various dates of grafting at poly house and open field conditions were resulting to be very significant. Under the conditions of polyhouse, bud bursting percentage and graft survival were much higher as compared to open field conditions.

Priyanka et al., (2017) found out when the graft operation was carried out in monthly intervals on 2-7 month old rootstock. they used procured scions for this purpose out of which 7 month old rootstock showed maximum graft success as compared to the other age rootstocks while performing soft wood grafting in jackfruit. There was no sprouting at all in the one which was 6 month old where least success was seen in the 5 month old. Minimum number of days for bud sprouting seen $\mathrm{n} 7$ month old and the maximum was seen in the 4 and 5 month old. In the 7 month old rootstock it was seen the maximum number of visible parameters ie., number of leaves, buds, maximum length, girth of shoot where as highest number of branches were seen in 4 month old one. The mortality of 7 month old one was least and 6 month old one was maximum.
Deshmukh et al., (2016) saw in their study in Khasi Mandarin the influence of rootstock's age and propagation methods (wedge grafting and T-budding) calculating various parameters like graft/bud success, plant survival, scion physiology and root morphology were studied. The 6 month old seedling wedge grafted showed maximum graft success and plant survival rate followed by the one wedge grafted 7 month old rootstock which was higher than the one done T-budding i.e., 12 month old seedling. Morpho-physiological traits, viz. higher individual leaf fresh weight $(0.42 \mathrm{~g})$ and dry weight $(0.16 \mathrm{~g})$, specific leaf weight (5.19 $\mathrm{mg} / \mathrm{cm} 2)$ and leaf thickness $(496.67 \mu \mathrm{m})$ in 6 month old. In addition, the leaf pigment contents, viz. chlorophyll 'a' $(0.77 \mathrm{mg} / \mathrm{g}$ tissue) and total chlorophyll content (1.12 $\mathrm{mg} / \mathrm{g}$ tissue) was found higher in 6 month old followed by 7 month old seedlings. And the overall results of this whole research showed that wedge grafting could be gainfully exploited for Khasi mandarin propagation.

Nguyen Van-Hang and Yen Chung-Ruey (2018) in their study determined the influence of rootstock age and season on success of cleft grafting and growth of grafted plants under greenhouse conditions. They conducted the study with two major factors i.e., factor A showed ages of rootstock (1,2,3 and 6 months olf) factor B showed two grafting seasons (summer and autumn). They found the result that the rootstock age and grafting season had a very significant effect on all the parameters that they were considering; sprouting time, percentage graft success, scion sprout length and number of new leaves per graft. The youngest rootstock got the best results for all the parameters and the best season for it was summer. So, according their study the age of rootstock affects the graft success.

Islam, et al., (2004) in their experiment on the inserted contact grafting in mango (Mangifera 
indica) was done to find out the best time and age of rootstock for grafting in best varieties of mango under conditions of Bangladesh. In this experiment they indicated that inserted contact grafting could be more successful in 16 May operations and the highest percentage of the grafts that survived $(56.82 \%)$ was recorded in 16 May operation 120 days after detachment of the grafts from the mother plant requiring less time (70.22 days) for graft success when they did grafting in $2 y / 0$ rootstock in cv. Amarpali (BARI Aam-3).

Sharma et al., (2017) carried out her research in CCSHAU, Hisar. th this research the germination and growth time of guava seedling was recorded under different growing conditions ie., green house and open field, on different dates using two media. Minimum days were recorded when grown in greenhouse conditions sown on first fortnight of august in cocopeat, whereas the other parameters such as; height of seedling, maximum germination, no. of leaves, stem diameter were seen when growth in greenhouse on first fortnight of September using cocopeat. In the same research the secod experiment was carried out where wedge grafting was done at different age of the seedlings under various conditions for growing. The minimum days required, maximum graft take, no. of sprouts of rootstock, scion length, number of leaves were all found in the 12 month old seedling grown in greenhouse conditions followed by $8^{\text {th }}$ and $16^{\text {th }}$ month ones. In both the experiments the interaction between growing conditions and period on seedling and wedge grafting was found more significant.

Das et al., (2018) carried out their study to standardize epicotyl and softwood grafting techniques under Tripura conditions taking under consideration the availability of mango stones, suitable grafting time, appropriate rootstock age and grafting height. In their study they found out that the time under which they are grafting, the techniques they used and the age of rootstock has a significant effect on the results seen in the research of 2 years.

Vanaja et al., (2017) performed their study of wedge grafting the guava seedlings in different months i.e., September, October, November, December, January, February, under $50 \%$ shade net and poly house conditions. Where the results showed that least number of days taken for $50 \%$ of graft sprouting, max percentage of graft sprouting, number of flushes per sprout; were seen in the plants grown under shade net whereas compared to the plants grown under poly house. The max graft sprout and other parameters were seen in plants grown in the month of January followed by December.

Doddamani et al., (2000) found out in their research that the maximum number of graft in Aonla was found when wedge grafting was done during $2^{\text {nd }}$ fortnight of May $(66.66 \%)$ followed by $60 \%$ when done in $1^{\text {st }}$ fortnight of May. Least success of graft was seen when done in $1^{\text {st } J u l y ~}(26.66 \%)$.

Amin et al., (1978a) performed in their study the softwood grafting in cashew during 197576 with a percentage of 71.4 as a success under the months of August in Anand area of Gujrat. He also has tried a lot of soft wood grafting trails in various other crops such as Aonla, Guava, jackfruit, phalsa, sapota and got success of $73.3,70.7,33.3,100.0,91.6 \%$ respectively in the month of of August in Anand. Later on he did his study on Mango and found that March to September is the months which are very beneficial for dry parts of Gujrat.

Kolekar et al., (1979) in their research worked on performing vegetative propagation of jackfruit and recorded the maximum success 
rate of $80 \%$ during the month of February through soft wood grafting followed by the month of October giving result of $60 \%$.

Hanekar (1980) studied softwood grafting in cashew crop and got $56 \%$ and $44 \%$ of success in the month of May and June, under the conditions of Dapoli respectively. Later on he also tried soft wood grafting in jackfruit and got maximum success rate of $41.66 \%$ in the month of May and according to him rainy season is not very suitable.

Konhar and Das (1955), studied the best results of softwood grafting in the crop of cashew in a whole year under the conditions of Bhubaneshwar conditions (Odisha) and concluded that this technique is very useful with a ranging success rate of $43-100 \%$ and which was seen maximum in the month of January. The highest went uptop 90-100\% which was seen in the month January and February, respectively. They also did a trial on the epicotyl grafting and had a result as a success after trying it throughout the whole year on 5 to 7 days old seedling with having a successful rate of 57-100 percent of grafttake, except in the month of March during which time the scions were not available in the market.

\section{References}

Amin, R.S., Soft wood grafting a new technique for hardwood plants current science, 47: 468-469 (1978a).

Asenjo C.F., Bull De colegio de Quimicos de, Puerto Rico, 10: 8-17.

Beshir W., Alemayeh M. and Dessalegn Y., and Tejada M., Effect of grafting time and technique on success rate of grafted Mango in Kalu district of Amhara region, North eastern Ethiopia (2019).

Bharathkumar T.R., 2019 Influence of Different Seed Treatments on Dormancy Breaking in Aonla (Phyllanthus emblica L.)

Chouksey S., et al., (2016) Effect of Different
Season and Deblading on Wedge Grafting in Guava (Psidium guajava L.) cv. Lucknow-49. International Journal of Agriculture Sciences, Volume 8, Issue 57, pp.-3151-3153.

Das B., Lembisanadevi H., Kandpal, B. K., Standardization of grafting of mango as affected by method time and rootstocks age under Tripura conditions, ICAR Research complex for NEH region, Tripura (2018).

Deshmukh NA., Patel RK., Krishappa R., Verma BC., Rymbai H., Assume SR., Lyngdoh P., Jha AK., Malhotra SK., influence of rootstock age and propagation methods on scion physiology and root morphology of khasi Mandarin (Citrus reticulata), ICAR research complex fo NEH region, Meghalaya (2016)

Doddamani, Hanamashetti S.H., PatilSI., Effect of season on success of wedge grafting in aonla (Emblica officinalis Gaertn)- 2000

Gurjar P.S., Singh R., performance of wedge grafting in aonla at poly house and open field conditions, Dept. of Horti JNKVV, Rewa-486001, MP, India (2012)

Hanekar, MA., Studies on vegetative propagation of cashew and jackfruit, Msc. Agri thesis, Konkan Krishividyapeeth, Dapoli, Maharashtra (1980)

Islam M.N., Rahim MA., Naher M.N.A., Azad M.I. and Shahjahan M., 2004. Effect of Time of Operation and Age of Rootstock on the Success of Inserted Contact Grafting in Mango. Asian Journal of Plant Sciences, $\quad 3$ : 636-641. DOI: 10.3923/ajps.2004.636.641

URL: https://scialert.net/abstract/?doi=ajps .2004.636.641

Jadia M. Sahu Y., S.S. Singh and S.P. Mishra, (2014-2015); to study suitable period of wedge grafting in guava under different conditions of Chitrakoot region. M.H. Chitrakoot Gramodya Vishwavidyalaya, Satna (MP) India.

Kaushal R., Rajput V., and Bhatia SK.,(2017) studies on wedge grafting in guava (Pisidium guajava) under open field conditions, dep. Of horticulture, 
CCSHAU, hisar, Haryana.

Kolekar, DT., Studies on propagation of jackfruit (Artocarpushetero phyllus Lan.) Msc. Agri Thesis, konkan krishi vidyapeeth, dapoli, Maharashtra (1979).

Konhar, T. and Das GC., Epicotyls and softwood grafting new technique of vegetative propagation of cashew in Odisha, cashew cauberie 7(3); 13-14 (1955).

Kumari A., Kumar J., Kumar A., Choudhary A., Singh SP., (2015) grafting triggers differential responses between scion and rootstock.

L. Hennig, C. Köhler (eds.), Plant Developmental Biology, Methods in Molecular Biology 655, DOI 10.1007/9781-60761-765-5_2, (C) Springer Science+Business Media, LLC 2010

Naik, A.G., and Chundawat, BS., (1993) In: Golden JublieeSymo. Horticultural Research- Changing Senerio, Bengalore, Horti. Soc. India, May 24-28, 1993, Abst. No. 18.6 p. 337.

Panchbhai D., Athavale R.B., Jogdande, Dalal S.R. Soft wood grafting - aonla propagation made easy. Agricultural Science Digest. 2006. (26): 71 - 72.

Patel RK., L. Basu, Bidyut C. deka and NA Deshmukh (December 2015); standardization of grafting time and methods in Sohiong (Prunus nepalensis L.) an underutilized fruit under mid hills of Meghalaya, Div of Horti, ICAR Research complex of NEH region, Meghalaya; India.

Priyanka H.L., Vinay GM., Kulapati H., Deepak
G. Nayan, Mamtha N.P.; effect of rootstock age on softwood grafting in jackfruit (2017)

Sastry, LW., Satyanarayana, MN., Srinivasan, M., and Subramanyam, V. (1956) J. Sci. Indus Res., 15: 70-80.

Sharma N., Effect of growing conditions and age of rootstock seedling on grafting success in guava (2017).

Srimathi P. Research focus on seed collection, processing and storage of aonla, jamun and ber. Ph.D. thesis, TNAU, Coimbatore, 2000.

Vanaja L., Swami D.V., Kumar B.P. and Subaramamma P., Effect of grafting time on growth and success rate of guava wedge grafts grown under shade net and poly house conditions, Int.J.Curr.Microbial.App.Sci (2017) 6(10); 771-779

Van-Hang Nguyen and Chung-ruey yen, Rootstock age and grafting season effect graft success and plant growth of papaya (Carica papaya L.) in greenhouse , national pingtung university of science and tech, department of Agr. And international cooperation, pingtung 91201, Taiwan (2018)

Wali, V.K., Bakshi, P., Jasrotia, A., Bhushan B. and Bakshi M. 2015. Aonla. SKUASTJammu. Pp. 7-30.

Wang Y Q. Plant grafting and its application in biological research, Chinese Sci Bull, 2011, 56: 35113517, doi: 10.1007/s11434011-4816-1.

\section{How to cite this article:}

Kanika and Deepika Saxena. 2020. A Review on Vegetative Propagation of Aonla. Int.J.Curr.Microbiol.App.Sci. 9(12): 607-616. doi: https://doi.org/10.20546/ijcmas.2020.912.072 